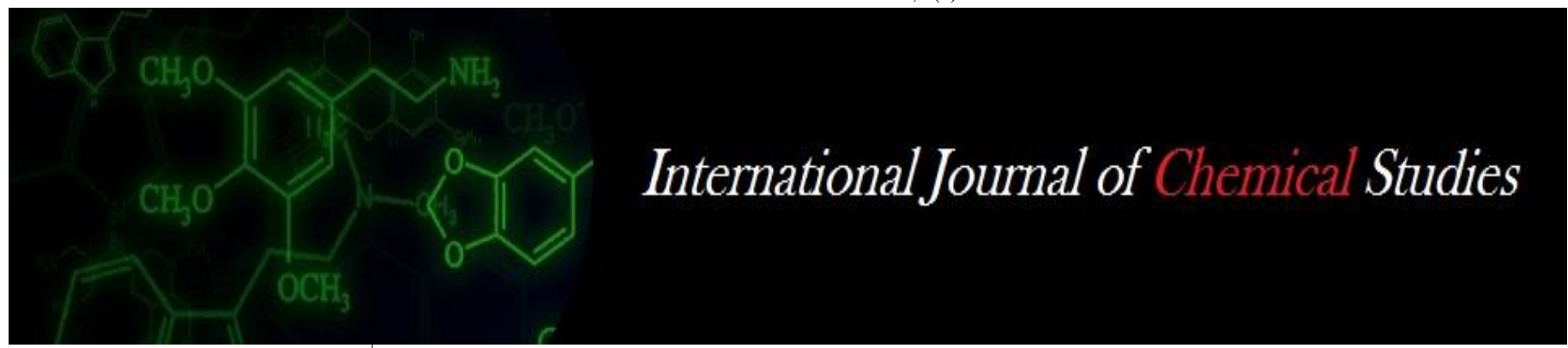

P-ISSN: 2349-8528

E-ISSN: 2321-4902

www.chemijournal.com

IJCS 2020; 8(4): 1634-1638

(C) 2020 IJCS

Received: 16-05-2020

Accepted: 18-06-2020

Amol Jagdale

Department of Soil Science and

Agricultural Chemistry,

Vasantrao Naik Marathwada

Krishi Vidyapeeth, Parbhani,

Maharashtra, India

\section{Anil Dhamak}

Department of Soil Science and

Agricultural Chemistry,

Vasantrao Naik Marathwada

Krishi Vidyapeeth, Parbhani,

Maharashtra, India

\section{Bhushan Pagar}

Department of Soil Science and Agricultural Chemistry,

Vasantrao Naik Marathwada

Krishi Vidyapeeth, Parbhani,

Maharashtra, India

\section{Pankaj Wagh}

Department of Soil Science and

Agricultural Chemistry,

Vasantrao Naik Marathwada

Krishi Vidyapeeth, Parbhani,

Maharashtra, India

\section{Effect of different organic formulations on growth and yield of soybean}

\author{
Amol Jagdale, Anil Dhamak, Bhushan Pagar and Pankaj Wagh
}

DOI: https://doi.org/10.22271/chemi.2020.v8.i4p.9844

\begin{abstract}
A field experiment was conducted during kharif season 2017 to Study the effect of organic formulations on growth, yield and soil nutrient dynamics in soybean at experimental farm, Department of Soil Science and Agricultural Chemistry, Vasantrao Naik Marathwada Krishi Vidyapeeth, Parbhani. The experiment was laid out with twelve treatments replicated three times in randomized block design. The treatment consisted of $\mathrm{T}_{1}$ - RDF (100\% NPK through fertilizer), $\mathrm{T}_{2}$ - Panchagavya only, $\mathrm{T}_{3}$-Jeevamruth only, $\mathrm{T}_{4}$ Beejamruth only, $\mathrm{T}_{5}$-Panchgavya + Beejamruth, $\mathrm{T}_{6}$ - Beejamruth + Jeevamruth, $\mathrm{T}_{7}-$ Panchgavya + Jeevamruth, $\mathrm{T}_{8}-\mathrm{RDF}+$ Beejamruth + Panchgavya, $\mathrm{T}_{9}-\mathrm{RDF}+$ Beejamruth + Jeevamruth, $\mathrm{T}_{10}-\mathrm{RDF}+$ Beejamruth + Jeevamruth+ Panchgavya, $\mathrm{T}_{11}-$ Beejamruth + Jeevamruth+ Panchgavya and $\mathrm{T}_{12}-100 \% \mathrm{~N}$ through FYM. The growth and yield attribute like plant height, leaf area, number of nodules per plant, seed yield and straw yield were significantly improved by application of RDF+ Beejamruth + Jeevamruth+ Panchgavya.
\end{abstract}

Keywords: Organic formulations, growth, yield, soybean

\section{Introduction}

Soybean (Glycine max L. Merrill) is an important oilseed pulse crop of the world. It became miracle crop of $20^{\text {th }}$ century and designated as "Golden Bean". Soybean is the cheapest source of protein and it is called "Poor man's meat". Soybean crop was introduced in sixties as supplementary oilseed crop to overcome the edible oil shortage in the country. Among all oilseeds crops, soybean occupied third position in the edible oil scenario of India. Nutritional point of view, soybean is an excellent source of protein and oil. It contains high amount of protein $(43.2 \%)$ and oil (19.5\%). It is also a rich source of vitamin A, B and D. It contains 3843 percent minerals and 2 per cent phospholipids. In addition, soybean is legume crop and having considerable potential to fix atmospheric nitrogen.

It is grown throughout the world with the largest production in United States, China, Brazil, Indonesia, Japan, Korea, and Argentina. In India, the area under soybean is 101.83 lakh ha with total production as 83.504 lakh MT and productivity of $822 \mathrm{~kg} \mathrm{ha}^{-1}$ (Anonymous, 2017) [1]. Madhya Pradhesh, Maharashtra and Rajashtan are the major soybean growth states. In Maharashtra, it is grown over an area of 34.00 lakh hectares with total production of 29.00 lakh MT with an average productivity of $841 \mathrm{~kg} \mathrm{ha}^{-1}$ (Anonymous, 2017) ${ }^{[1]}$.

Any improvement in agricultural system that results in higher production should reduce the negative environment impact of agriculture and enhance the sustainability of the system. One such approach is the effectiveness of conventional mineral fertilizers. Some organic formulations like Panchagavya, Beejamruth, Jeevamruth, Amritmitti and Amritjal obtained from cow and plant are used in agricultural and horticultural crop and many beneficial effect in the term of enhancement of yield and quality of have been reported (Gore and Shreenivasa, 2011) ${ }^{[3]}$.

\section{Material and Methods}

A field experiment was conducted during kharif season 2017 to study the effect of organic formulations on growth, yield and soil nutrient dynamics in soybean at Research Farm of Soil Science and Agricultural Chemistry, Vasantrao Naik Marathwada Krishi Vidyapeeth, Parbhani. The initial soil pH was 7.91, EC-0.24 dSm${ }^{-1}$, Organic Carbon- $4.10 \mathrm{~g} \mathrm{~kg}^{-1}$, Calcium carbonate $-4.05 \%$, available nitrogen- $151.00 \mathrm{~kg} \mathrm{ha}^{-1}$, Phosphorus -12.51 , Potassium- $510.18 \mathrm{~kg}$
Amol Jagdale

Department of Soil Science and Agricultural Chemistry,

Vasantrao Naik Marathwada

Krishi Vidyapeeth, Parbhani,

Maharashtra, India 
$\mathrm{ha}^{-1}$. The initial micronutrient status was DTPA Copper-1.12, Mangnease-5.43, Zinc-0.52 and Ferrous - $3.10 \mathrm{mg} \mathrm{kg}^{-1}$. The soil was clayey in texture, moderately alkaline in reaction, medium in available nitrogen, phosphorus and sufficient in available potassium and low in sulphur and iron.

The field experiment was carried out on soybean crop (Variety MAU-158) in kharif season during year 2017-18. After completion of preparatory tillage operations, the experiment was laid out in randomized block design comprising (12) treatments and replicated (3) times.

\section{Treatments details}

Twelve treatments were formulated to evaluate the effect of organic formulations on growth, yield and soil nutrient dynamics in soybean. The details of treatment are as follows

The details of treatment are as follows

\begin{tabular}{|c|c|}
\hline Treatment & Treatments detail \\
\hline $\mathrm{T}_{1}$ & RDF (100\% NPK through fertilizer ) \\
\hline $\mathrm{T}_{2}$ & Panchagavya only \\
\hline $\mathrm{T}_{3}$ & Jeevamruth only \\
\hline $\mathrm{T}_{4}$ & Beejamruth only \\
\hline $\mathrm{T}_{5}$ & Panchgavya + Beejamruth \\
\hline $\mathrm{T}_{6}$ & Beejamruth + Jeevamruth \\
\hline $\mathrm{T}_{7}$ & Panchgavya + Jeevamruth \\
\hline $\mathrm{T}_{8}$ & RDF + Beejamruth + Panchgavya \\
\hline $\mathrm{T}_{9}$ & RDF + Beejamruth + Jeevamruth \\
\hline $\mathrm{T}_{10}$ & RDF+ Beejamruth + Jeevamruth+ Panchgavya \\
\hline $\mathrm{T}_{11}$ & Beejamruth + Jeevamruth+ Panchgavya \\
\hline $\mathrm{T}_{12}$ & 100\% N through FYM \\
\hline
\end{tabular}

\section{Results and Discussion \\ Effect of organic formulations on growth of soybean Plant height}

The data of plant height of soybean at various growth stages as influenced by different organic formulations are presented in Table 1. Plant height showed significant differences due to the effect of different treatments of organic formulation at various growth stages. The data presented in Table 1 revealed that the plant height at flowering, pod development and harvesting stages was varied from 65.41 to $79.89 \mathrm{~cm}, 98.70$ to $118.43 \mathrm{~cm}$ and 101.20 to $121.24 \mathrm{~cm}$ with an average of 70.64 , 104.34 and $106.13 \mathrm{~cm}$, respectively. Significantly maximum height with RDF + Beejamruth + Jeevamruth + Panchagavya $\left(\mathrm{T}_{10}\right)$ treatment followed by $\mathrm{T}_{8}, \mathrm{~T}_{9}$ and $\mathrm{T}_{1}$ treatment and treatment $\mathrm{T}_{10}$ is significantly superior over rest of the treatments. However, minimum plant height was noticed in treatment $\mathrm{T}_{4}$ i.e. application of Beejamruth only at all the growth stages of crop. The significant increase in plant height with application of organic formulation along with chemical fertilizer can be attributed to the fact that these organic formulations enhance plant vigour and strenghthen the stalk and enhance the cell division and cell elongation resulting in increasing positive effect of growth parameter. The higher plant height may be due to the positive effect of application of Panchagavya, Beejamruth, and Jeevamruth along with chemical fertilizer on the vegetative growth and accumulation of metabolic material. Similar result have been reported by Palve et al (2011) ${ }^{[4]}$ and Tharmaraj et al (2011) ${ }^{[10]}$.

Table 1: Effect of organic formulations on plant height at various growth stages of soybean

\begin{tabular}{|c|c|c|c|}
\hline Treatments detail & \multicolumn{3}{|c|}{ Plant height (cm) } \\
\hline & Flowering & Pod development & Harvesting \\
\hline $\mathrm{T}_{1}:$ RDF (100\% NPK through fertilizer) & 72.60 & 107.04 & 107.24 \\
\hline $\mathrm{T}_{2:}$ Panchagavya only & 67.24 & 94.98 & 101.92 \\
\hline $\mathrm{T}_{3:}$ Jeevamruth only & 66.37 & 99.47 & 101.63 \\
\hline $\mathrm{T}_{4}$ : Beejamruth only & 65.41 & 98.70 & 101.20 \\
\hline $\mathrm{T}_{5:}$ Panchgavya + Beejamruth & 69.68 & 102.04 & 102.67 \\
\hline $\mathrm{T}_{6}:$ Beejamruth + Jeevamruth & 68.87 & 99.77 & 102.43 \\
\hline $\mathrm{T}_{7}$ Panchgavya + Jeevamruth & 69.49 & 101.63 & 102.58 \\
\hline $\mathrm{T}_{8}: \mathrm{RDF}+$ Beejamruth + Panchgavya & 73.94 & 109.61 & 110.69 \\
\hline $\mathrm{T}_{9}: \mathrm{RDF}+$ Beejamruth + Jeevamruth & 72.92 & 109.57 & 110.60 \\
\hline $\mathrm{T}_{10}: \mathrm{RDF}+$ Beejamruth + Jeevamruth+ Panchgavya & 79.89 & 118.43 & 121.24 \\
\hline $\mathrm{T}_{11: \text { Beejamruth + Jeevamruth+ Panchgavya }}$ & 71.28 & 106.33 & 106.33 \\
\hline $\mathrm{T}_{12}:$ 100\% N through FYM & 70.07 & 104.55 & 106.14 \\
\hline Mean & 70.64 & 104.34 & 106.13 \\
\hline SE \pm & 2.60 & 4.05 & 3.08 \\
\hline CD at 5\% & 7.64 & 11.89 & 9.06 \\
\hline CV & 6.38 & 6.73 & 5.04 \\
\hline
\end{tabular}

\section{Leaf area}

The result on leaf area as influenced by the application of organic formulation at various growth stages of soybean are presented in Table 2. There was continuous build up of leaf area in soybean with advancing growth stages. The results also indicated that the application of organic formulations along with the recommended dose of fertilizer significantly influenced leaf area of soybean at various growth stages over single application of organic formulations and RDF. Leaf area varied from 30.94 to $50.15 \mathrm{~cm}^{2}, 56.16$ to $75.08 \mathrm{~cm}^{2}$ and 57.91 to $84.66 \mathrm{~cm}^{2}$ at flowering, pod development and harvesting stage of soybean. The highest leaf area was recorded with $\mathrm{T}_{10}$ (RDF + Beejamruth + Jeevamruth + Panchagavya) treatment followed by $\mathrm{T}_{8}(\mathrm{RDF}+$ Beejamruth + Panchagavya) treatment at all stages of growth in soybean during the year of experimentation. These results opined that the inclusion of organic formulations with recommended dose of fertilizer has synergetic effect. The increase in leaf area per plant with increasing age in present investigation is in accordance with the findings reported by Sanjutha et al (2008) ${ }^{[9]}$ and Patil et al (2016) ${ }^{[7]}$. 
Table 2: Effect of organic formulations on leaf area at various growth stages of soybean

\begin{tabular}{|c|c|c|c|}
\hline Treatments detail & \multicolumn{3}{|c|}{ Leaf area (Sq cm) } \\
\hline & Flowering & Pod development & Harvesting \\
\hline $\mathrm{T}_{1}:$ RDF (100\% NPK through fertilizer) & 40.75 & 70.93 & 71.95 \\
\hline $\mathrm{T}_{2:}$ Panchagavya only & 33.07 & 60.83 & 62.09 \\
\hline $\mathrm{T}_{3:}$ Jeevamruth only & 32.72 & 58.12 & 60.92 \\
\hline $\mathrm{T}_{4}$ : Beejamruth only & 30.94 & 56.16 & 57.91 \\
\hline $\mathrm{T}_{5}$ Panchgavya + Beejamruth & 37.68 & 65.18 & 67.65 \\
\hline $\mathrm{T}_{6}$ : Beejamruth + Jeevamruth & 34.42 & 63.26 & 64.17 \\
\hline $\mathrm{T}_{7}$ Panchgavya + Jeevamruth & 36.83 & 64.58 & 65.17 \\
\hline $\mathrm{T}_{8}: \mathrm{RDF}+$ Bejamruth + Panchgavya & 43.71 & 72.62 & 74.69 \\
\hline $\mathrm{T}_{9}: \mathrm{RDF}+$ Beejamruth + Jeevamruth & 42.88 & 71.33 & 72.71 \\
\hline $\mathrm{T}_{10}: \mathrm{RDF}+$ Beejamruth + Jeevamruth+ Panchgavya & 50.15 & 75.08 & 84.66 \\
\hline $\mathrm{T}_{11:}$ Beejamruth + Jeevamruth+ Panchgavya & 39.60 & 69.64 & 70.20 \\
\hline $\mathrm{T}_{12}: 100 \%$ N through FYM & 38.61 & 67.71 & 68.35 \\
\hline Grand mean & 38.44 & 66.28 & 68.37 \\
\hline SE \pm & 1.70 & 2.12 & 2.32 \\
\hline CD at 5\% & 4.99 & 6.22 & 6.82 \\
\hline CV & 7.66 & 6.22 & 6.82 \\
\hline
\end{tabular}

\section{Number of root nodules and fresh weight of root nodules per plant}

The data on number of nodules per plant and fresh weight of nodules per plant at 60 DAS as influenced by different treatment of organic formulations are presented in Table 3. Nodulation in soybean was significantly influenced by application of various organic formulations along with RDF. The data narrated in Table 7 shows that the number of nodules per plant and nodules fresh weight were increased significantly due to combination of organic formulations with RDF over RDF and alone application of organic formulations. Significantly higher value of number of nodules and fresh weight of nodules per plant (32.91 and 0.45) was recorded in $\mathrm{RDF}+$ Beejamruth + jeevamruth + Panchagavya $\left(\mathrm{T}_{10}\right)$ treatment while lowest was recorded in $\mathrm{T}_{4}$ treatment. Similar finding have reported by Devi et al (2013) ${ }^{[2]}$.

Table 3: Effect of organic formulation on number of root nodules and fresh weight of root nodules per plant at 60 DAS of soybean

\begin{tabular}{|c|c|c|}
\hline Treatments detail & No. of root nodules & Fresh wt. of root nodules (gm) \\
\hline $\mathrm{T}_{1}: \mathrm{RDF}$ (100\% NPK through fertilizer) & 28.72 & 0.34 \\
\hline $\mathrm{T}_{2:}$ Panchagavya only & 24.62 & 0.26 \\
\hline $\mathrm{T}_{3}$ Jeevamruth only & 23.59 & 0.26 \\
\hline $\mathrm{T}_{4}$ : Beejamruth only & 22.37 & 0.24 \\
\hline $\mathrm{T}_{5}$ Panchgavya + Beejamruth & 26.91 & 0.32 \\
\hline $\mathrm{T}_{6}:$ Beejamruth + Jeevamruth & 25.77 & 0.29 \\
\hline $\mathrm{T}_{7}:$ Panchgavya + Jeevamruth & 25.98 & 0.31 \\
\hline $\mathrm{T}_{8}: \mathrm{RDF}+$ Bejamruth + Panchgavya & 29.47 & 0.36 \\
\hline $\mathrm{T}_{9}: \mathrm{RDF}+$ Beejamruth + Jeevamruth & 29.29 & 0.35 \\
\hline $\mathrm{T}_{10}: \mathrm{RDF}+$ Beejamruth + Jeevamruth+ Panchgavya & 32.91 & 0.45 \\
\hline $\mathrm{T}_{11: \text { Beejamruth + Jeevamruth+ Panchgavya }}$ & 28.60 & 0.33 \\
\hline $\mathrm{T}_{12}: 100 \%$ N through FYM & 27.66 & 0.32 \\
\hline Grand mean & 27.15 & 0.32 \\
\hline SE \pm & 1.04 & 0.02 \\
\hline CD at 5\% & 3.06 & 0.07 \\
\hline CV & 6.67 & 11.62 \\
\hline
\end{tabular}

\section{Effect of organic formulations on yield of soybean Seed yield}

The data on seed yield of soybean $\left(\mathrm{kg} \mathrm{ha}^{-1}\right)$ as influenced by different treatments are synthesized in Table 4. There was significant increase in the seed yield of soybean due to application of organic formulations along with recommended dose of fertilizer as compared to RDF and application of only organic formulations. The results revealed that the seed yield of soybean varied in the range of 1344.54 to $2368.38 \mathrm{~kg} \mathrm{ha}^{-1}$. Significantly highest soybean seed yield was obtained with treatment $\mathrm{T}_{10}$ receiving $\mathrm{RDF}+$ Beejamruth + Jeevamruth + Panchagavya $\left(2368.38 \mathrm{~kg} \mathrm{ha}^{-1}\right)$ followed by treatment $\mathrm{T}_{8}$ receiving RDF + Beejamruth + Panchagavya $(2139.76 \mathrm{~kg}$ ha ${ }^{1}$ ) and lowest was found in $\mathrm{T}_{4}$ treatment $\left(1289.17 \mathrm{~kg} \mathrm{ha}^{-1}\right)$. However, the magnitude of increase grain yield under treatment $\mathrm{T}_{10}$ receiving $\mathrm{RDF}+$ Beejamruth + Jeevamruth + Panchagavya being about 13.79 percent over only RDF. Significantly higher seed yield of soybean was observed in application of Beejamruth + Jeevamruth +Panchagavya along with RDF due to adequate supply of required nutrient through chemical fertilizer at early stage of plant growth and also due to overall improvement in soil Physico- chemical and biological properties due to combined application of organic formulations and inorganic fertilizers. The better nutrient availability and nutrient uptake increased the growth and yield of crop. These results are in compliance with the finding of Gore and Sreenivasa (2011) ${ }^{[3]}$, Yadhav et al (2017) ${ }^{[11]}$, Patil and Padmani (2007) ${ }^{[6]}$, Patel et al (2013) ${ }^{[5]}$ and Patil and Udmale (2016) ${ }^{[7]}$. 
Table 4: Effect of organic formulations on seed yield of soybean

\begin{tabular}{|c|c|c|}
\hline Treatments detail & Seed yield $\left(\mathrm{kg} \mathrm{ha}^{-1}\right)$ & \% increase over only RDF \\
\hline $\mathrm{T}_{1}:$ RDF (100\% NPK through fertilizer) & 2081.93 & - \\
\hline $\mathrm{T}_{2:}$ Panchagavya only & 1378.72 & - \\
\hline $\mathrm{T}_{3:}$ Jeevamruth only & 1344.54 & - \\
\hline $\mathrm{T}_{4}$ : Beejamruth only & 1289.17 & - \\
\hline T5: Panchgavya + Beejamruth & 1844.21 & - \\
\hline T6: Beejamruth + Jeevamruth & 1618.09 & - \\
\hline $\mathrm{T}_{7}$ : Panchgavya + Jeevamruth & 1776.85 & - \\
\hline $\mathrm{T}_{8}: \mathrm{RDF}+$ Beejamruth + Panchgavya & 2139.76 & 2.78 \\
\hline $\mathrm{T}_{9}: \mathrm{RDF}+$ Beejamruth + Jeevamruth & 2095.88 & 0.67 \\
\hline $\mathrm{T}_{10:}$ RDF+ Beejamruth + Jeevamruth+ Panchgavya & 2368.38 & 13.79 \\
\hline $\mathrm{T}_{11:}$ Beejamruth + Jeevamruth+ Panchgavya & 1892.45 & - \\
\hline $\mathrm{T}_{12}: 100 \% \mathrm{~N}$ through FYM & 1888.88 & - \\
\hline Grand mean & 1809.90 & \\
\hline $\mathrm{SE} \pm$ & 65.16 & \\
\hline CD at $5 \%$ & 191.13 & \\
\hline $\mathrm{CV}$ & 6.23 & \\
\hline
\end{tabular}

\section{Straw yield}

The data on straw yield of soybean are presented in Table 2. The Straw yield of soybean ranged from 1223.60 to 2152.00 $\mathrm{kg} \mathrm{ha}^{-1}$. The straw yield was highest $\left(2152.00 \mathrm{~kg} \mathrm{ha}^{-1}\right)$ with the treatment $\mathrm{T}_{10}$ (RDF + Beejamruth + Jeevamruth + Panchagavya). The lowest straw yield was (1223.60 kg ha-1) was recorded in treatment $\mathrm{T}_{4}$ (Beejamruth). The application of Beejamruth + Jeevamruth + Panchagavya might have resulted in the better availability of nutrient throughout the crop growth. This is mediated through biological processes as noticed by higher microbial activity; soil enzymatic activity and plant growth promoter present it. These result are in combination with the finding of Gore and Sreenivasa (2011) ${ }^{[3]}$, Sahay et al (2016) ${ }^{[8]}$, Zadode et al (2014) ${ }^{[12]}$, Yadav et al (2017) ${ }^{[11]}$ and Patil and Udmale (2016) ${ }^{[7]}$.

Table 5: Effect of organic formulations on straw yield of soybean

\begin{tabular}{|c|c|c|}
\hline Treatments detail & straw yield $\left(\mathbf{k g ~ h a}^{\mathbf{- 1}}\right)$ & \% increase over control \\
\hline $\mathrm{T}_{1}: \mathrm{RDF}(100 \%$ NPK through fertilizer) & 1999.20 & - \\
\hline $\mathrm{T}_{2:}$ Panchagavya only & 1288.36 & - \\
\hline $\mathrm{T}_{3}$ Jeevamruth only & 1272.40 & - \\
\hline $\mathrm{T}_{4}$ : Beejamruth only & 1223.60 & - \\
\hline $\mathrm{T}_{5}$ Panchgavya + Beejamruth & 1748.00 & - \\
\hline $\mathrm{T}_{6}:$ Beejamruth + Jeevamruth & 1544.00 & - \\
\hline $\mathrm{T}_{7}:$ Panchgavya + Jeevamruth & 1698.00 & 3.20 \\
\hline $\mathrm{T}_{8}: \mathrm{RDF}+$ Beejamruth + Panchgavya & 2063.00 & 0.20 \\
\hline $\mathrm{T}_{9}: \mathrm{RDF}+$ Beejamruth + Jeevamruth & 2003.00 & - \\
\hline $\mathrm{T}_{10}: \mathrm{RDF}+$ Beejamruth + Jeevamruth + Panchgavya & 2152.00 & - \\
\hline $\mathrm{T}_{11:}$ Beejamruth + Jeevamruth+ Panchgavya & 1720.40 & \\
\hline $\mathrm{T}_{12}: 100 \% \mathrm{~N}$ through FYM & 1748.30 & \\
\hline Grand mean & 1705.02 & \\
\hline SE \pm & 59.39 & \\
\hline CD at $5 \%$ & 174.19 & \\
\hline CV & 6.03 & \\
\hline
\end{tabular}

\section{Conclusion-}

The Applications of organic formulations RDF+ Beejamruth + Jeevamruth + Panchagavya significantly enhanced growth and yield of soybean.

\section{References}

1. Anonymous. www. Sopa org, 2017.

2. Devi KN, Singh TB, Singh H, Athokpam, Singh NB, Shamurailatpam Diana. Influence of inorganic, biological and organic manures on nodulation and yield of soybean (Glycine max Merril L.) and soil properties. Australian Journal of Crop Science. 2013; 7(9):1407-1415.

3. Gore N, Shreenivasa MN. Influence of liquid organic manures on growth, nutrient content and yield of tomato. Karanataka Journal .Agric. Sci. 2011; 24(2):153-157.

4. Palve DK, Oza SR, Jadhav JD, Ghule PL. Growth studies of soybean under different nutritional requirement. Adv. Res. J Crop Improv. 2011; 2(1):86-91.
5. Patel MM, Patel DM, Patel M. Effect of panchagavya on growth and yield of cowpea (Vigna unguiculata (L.) walp.). A International e-Journal. 2013; 2(3):313-317.

6. Patil AB, Padmani DR. Nutrient uptake pattern of pigeon pea (Cajanus cajan) as influenced by integrated nutrient management. Internat. J Agric. Sci. 2007; 3(2):176-178.

7. Patil HM, Udmale KB. Response of different organic inputs on growth and yield of soyabean on inceptisol. Journal of Agriculture Science. 2016; 6(5):139-144.

8. Sahay A, Pratap T, Tyagi S, Nanher AH, Singh R, Singh $\mathrm{SS}$, et al. Effect of integrated nutrient management on growth, yield and quality of pigeonpea (cajanus cajan L.millsp.) cv. Pusa 9., The Bioscan. 2016; 11(1):293-296.

9. Sanjutha S, Subramanian S, Indu RC, Maheswari J. Integrated nutrient management in andrographis paniculata. Research Journal of Agriculture and Biological Sciences. 2008; 4(2):141-145.

10. Tharmaraj K, Ganesh P, Kumar R, Anandan A, Kolanjinathan K. A critical review on panchagavya - a 
boon plant growth. International Journal of Pharmaceutical \& Biological Archives. 2011; 2(6):16111614.

11. Yadav JK, Sharma M, Yadav R, Yadav SK. Effect of different organic manures on growth and yield of chickpea (Cicer arietinum L.). Journal of Pharmacognosy and Phytochemistry. 2017; 6(5):1857-1860.

12. Zadode RS, Sethi HN, Vilekar SC. Growth and yield of pigeon pea as affected by organic and inorganic fertilizer. Advanced Research Journal of Crop Improvement. 2014; 5(2):97-10. 